\title{
Knockdown of CRF1 Receptors in the Ventral Tegmental Area Attenuates Cue- and Acute Food Deprivation Stress- Induced Cocaine Seeking in Mice
}

\author{
Nicola A. Chen, ${ }^{1 \star}$ Bianca Jupp, ${ }^{1 *}$ Yehezkel Sztainberg, ${ }^{2}$ Maya Lebow, ${ }^{2}$ Robyn M. Brown, ${ }^{1}$ Jee Hyun Kim, ${ }^{1}$ Alon Chen,,${ }^{2,3}$ \\ and Andrew J. Lawrence ${ }^{1}$ \\ ${ }^{1}$ Florey Institute of Neuroscience and Mental Health, University of Melbourne, Parkville, Australia 3010, ${ }^{2}$ Department of Neurobiology, Weizmann Institute \\ of Science, Rehovot 76100, Israel, and ${ }^{3}$ Department of Stress Neurobiology and Neurogenetics, Max-Planck Institute of Psychiatry, Munich 80804, Germany
}

Corticotrophin-releasing factor (CRF) modulates the influence of stress on cocaine reward and reward seeking acting at multiple sites, including the ventral tegmental area (VTA). There is controversy, however, concerning the contribution of CRF receptor type 1 (CRFR1) to this effect and whether CRF within the VTA is involved in other aspects of reward seeking independent of acute stress. Here we examine the role of CRFR1 within the VTA in relation to cocaine and natural reward using viral delivery of short hairpin RNAs (lenti-shCRFR1) and investigate the effect on operant self-administration and motivation to self-administer, as well as stress-and cue-induced reward seeking in mice. While knockdown of CRFR1 in the VTA had no effect on self-administration behavior for either cocaine or sucrose, it effectively blocked acute food deprivation stress-induced reinstatement of cocaine seeking. We also observed reduced cue-induced cocaine seeking assessed in a single extinction session after extended abstinence, but cue-induced sucrose seeking was unaffected, suggesting dissociation between the contribution of CRFR1 in the VTA in cocaine reward and sucrose and cocaine seeking. Further, our data indicate a role for VTA CRFR1 signaling in cocaine seeking associated with, and independent of, stress potentially involving conditioning and/or salience attribution of cocaine reward-related cues. CRFR1 signaling in the VTA therefore presents a target for convergent effects of both cue- and stress-induced cocaine-seeking pathways.

Key words: cocaine; cue; mouse; relapse; stress; VTA

\section{Introduction}

A major problem in the treatment of substance use disorders is the enduring propensity to relapse, even after extended periods of abstinence (O'Brien, 1997). Indeed, $40-60 \%$ of patients treated for drug or alcohol dependence will return to active substance use within 1 year (McLellan et al., 2000). Craving and relapse to drug use can be triggered in individuals by environmental stimuli that have become conditioned to the action of drugs (O'Brien et al., 1992) or by stressors (Sinha et al., 2011), a phenomenon which is

Received Oct. 8, 2012; revised July 11, 2014; accepted July 15, 2014.

Author contributions: B.J., A.C., and A.J.L. designed research; N.A.C., B.J., Y.S., M.L., R.M.B., J.H.K., and A.J.L. performed research; A.C. contributed unpublished reagents/analytic tools; N.A.C., B.J., and A.J.L. analyzed data; N.C., B.J., and A.J.L. wrote the paper.

These studies were supported by the National Health and Medical Research Council of Australia (NHMRC; project grant 1021227) of which A.J.L. is a Principal Research Fellow, as well as an FP7 Grant (A.C.) from the European Research Council (260463) and a research Grant from the Israel Science Foundation (A.C.). B.J. is supported by fellowships from the NHMRC and AXA Research Fund. R.M.B. is a Peter Doherty Early Career Research Fellow. J.H.K. is a DECRA Fellow supported by the Australian Research Council. Financial support from the Besen Family Foundation and the Pratt Trust, plus the Victorian Government's Operational Infrastructure Support Program, are acknowledged. We acknowledge the expert technical assistance of Associate Professor Ross Bathgate, Dr. Craig Smith, and Sharon Layfield.

${ }^{*}$ N.A.C. and B.J. contributed equally to this study.

The authors declare no competing financial interests.

Correspondence should be addressed to Andrew J Lawrence, Florey Institute of Neuroscience and Mental Health, Parkville, Victoria, Australia 3010. E-mail: andrew.lawrence@florey.edu.au.

DOI:10.1523/JNEUROSCI.4763-12.2014

Copyright $\odot 2014$ the authors $\quad 0270-6474 / 14 / 3411560-11 \$ 15.00 / 0$ also observed in rodent models of drug use, with both stress and cue exposure capable of inducing drug seeking in abstinent animals (Bossert et al., 2013). Corticotrophin-releasing factor (CRF) is a neuropeptide mediating hormonal, autonomic, and behavioral responses to stress, and a considerable literature implicates CRF in mediating the link between stress and addiction (Zorrilla et al., 2014). As such, rodent models of relapse suggest CRF as a key mediator of stress-induced reinstatement of drug seeking (Shalev et al., 2010). There is, however, also evidence for a role of CRF in the learned association between drug experience and environmental cues (DeVries et al., 1998), and CRF has been implicated in cue-induced drug seeking (Goeders and Clampitt, 2002; Moffett and Goeders, 2007), potentially as a result of the stress associated with exposure to such cues (DeVries and Pert, 1998; Sinha et al., 2003). Systemic receptor antagonist studies implicate CRF receptor type 1 (CRFR1) in both stress- and cue-induced drug seeking (Shaham et al., 1998; Goeders and Clampitt, 2002; Moffett and Goeders, 2007); however, the loci of this action are still equivocal.

The ventral tegmental area (VTA) is a major neural substrate underlying reward-seeking behavior, and is implicated in cue conditioning, as well as cue- and stress-induced cocaine seeking in rats (McFarland et al., 2004; Feltenstein and See, 2008). Prior cocaine exposure allows CRF control over firing of VTA neurons (Wang et al., 2005), and infusion of CRF into the VTA can rein- 
state cocaine-seeking rats, though controversy surrounds which CRF receptor subtype within the VTA mediates stressinduced reinstatement (Wang et al., 2005, 2007; Blacktop et al., 2011). In this study we took a novel approach using viralmediated knockdown to investigate the contribution of CRFR1 within the VTA in aspects of cocaine and natural reward self-administration, and cue-induced as well as stressinduced reward seeking.

\section{Materials and Methods}

Animals. All experiments were performed in accordance with the Prevention of Cruelty to Animals Act 1986 under the guidelines of the National Health and Medical Research Council Code of Practice for the Care and Use of Animals for Experimental Purposes in Australia and approved by the Animal Ethics Committee at the Florey Institute of Neuroscience and Mental Health. Adult male C57BL/6J mice (Animal Resource Center), were used for all experiments and were maintained on a reversed $12 \mathrm{~h}$ light/dark cycle with ad libitum access to water and were maintained at $\sim 95 \%$ of free-feeding weight.

Quantification of VTA-CRFR1 and CRFR2 transcript levels, plus validation of viral knockdown. To determine the endogenous levels of CRFR1 and CRFR2 in the VTA, adult C57BL/6J mice were used ( $n=8)$. Immediately after decapitation, the brain was removed and placed in a steel brain matrix, $1.0 \mathrm{~mm}$, coronal (model 51386: Stoelting). The brains were sliced into $2 \mathrm{~mm}$ slices using standard razor blades and were quickly frozen on dry ice. The right and left VTA were punched out using a 16G microdissecting needle and immediately stored at $-80^{\circ} \mathrm{C}$.

RNA extraction was performed using 5 PRIME PerfectPure RNA Cell $\&$ Tissue kit (5 Prime). RNA preparations were reverse transcribed to generate cDNA using High Capacity cDNA Reverse Transcription Kit (Applied Biosystems). The cDNA products were used as templates for Real-Time PCR analysis. Primer sequences as follows: CRFR2:TACCGAATCGCCCTCATTGT, CCACGCGATGTTTCTCAGAAT; CRFR1: TGCCAGGAGATTCTCAACGAA, AAAGCCGAGATGAGGTTCCAG; GFP: CATGCCCGAAGGCTACGT, CGATGCCCTTCAGCTCGAT; DMRTA2: CGAAGTCTTTGGCTCGGTTT, AATTTGGCCTCTGCG CCC; and HPRT1: GCAGTACAGCCCCAAAATGG, GGTCCTTTTCA CCAGCAAGCT.

Real-time PCRs were performed on a 7500 Real-time PCR system using fluorescent SYBR Green technology (Applied Biosystems). Reaction protocols had the following format: $10 \mathrm{~min}$ at $95^{\circ} \mathrm{C}$ for enzyme activation followed by 40 cycles of $15 \mathrm{~s}$ at $94^{\circ} \mathrm{C}$ and $60 \mathrm{~s}$ at $60^{\circ} \mathrm{C}$. Melting curve analysis checked the specificity of the amplification products. All reactions contained the same amount of cDNA, $10 \mu \mathrm{l}$ Master Mix, and $250 \mathrm{~nm}$ primers to a final volume of $20 \mu \mathrm{l}$. Real-time data were normalized to the housekeeping gene HPRT1.

Validation of VTA CRFR1 knockdown in vivo was performed in a similar manner to our previous studies. Adult C57BL/6J mice $(n=6)$ were injected directly into the VTA with shCRFR1 or shControl lenti viruses, as detailed below and previously described (Sztainberg et al., 2010). One week post injection, the VTA was microdissected as above, and right and left punches stored separately to accurately measure GFP on each side ( $n=12$; two separate samples per mouse). GFP mRNA was measured as an indicator of site-specific injection. Individual samples with minimal GFP mRNA were excluded $(n=2)$. Dmrta2 mRNA was also measured as a marker for VTA-specific microdissection to control for substantia nigra contamination of the sample. Samples with minimal Dmrta2 mRNA were thus also excluded $(n=1)$.

Intracerebral injections of lentiviral vectors. Mice received bilateral VTA injections ( $1 \mu \mathrm{l}$ per side, $0.25 \mu \mathrm{l} / \mathrm{min}$ ) of lenti-virus with a GFP reporter containing either shRNA targeted against CRFR1 mRNA (shCRFR1) or a control construct containing a scrambled shRNA sequence (shControl virus; Sztainberg et al., 2010, 2011). Stereotaxic coordinates for injections relative to bregma were posterior $-3.0 \mathrm{~mm}$; lateral $0.45 \mathrm{~mm}$, and ventral $-4.4 \mathrm{~mm}$ (Paxinos and Franklin, 2001). An additional group of mice received shCRFR1 virus in the lateral thalamus (posterior $-3.0 \mathrm{~mm}$; lateral $1.45 \mathrm{~mm}$, and ventral $-3.0 \mathrm{~mm}$ ). Mice were allowed to recover for
3 weeks to allow for optimal viral expression before commencing behavioral studies (Sztainberg et al., 2010).

Operant self-administration and cue-induced reward seeking. Operant self-administration of oral sucrose $(10 \% \mathrm{w} / \mathrm{v}$; shCRFR $1 n=20$; shControl $n=9)$ or intravenous cocaine $(0.5 \mathrm{mg} / \mathrm{kg} /$ infusion; shCRFR $1 n=27$; shControl $n=10$ ) was conducted as previously described (Brown et al., 2009; McPherson et al., 2010).

Briefly, mice undergoing cocaine self-administration were surgically implanted under isoflurane anesthesia $(1.5-1.8 \%$ in $1 \mathrm{~L} / \mathrm{min}$ air) and perioperative meloxicam analgesia $(3 \mathrm{mg} / \mathrm{kg}$, i.p.) with a jugular catheter to enable intravenous infusion of cocaine and allowed to recover for 2-3 $\mathrm{d}$ before commencement of self-administration sessions. Catheters were flushed daily with $0.02 \mathrm{ml}$ of a solution of $10 \mathrm{U}$ heparinized saline before self-administration and $90 \mathrm{U}$ following completion of each session. The patency of the catheters was evaluated periodically using $0.02 \mathrm{ml}$ of ketamine $(15 \mathrm{mg} / \mathrm{ml})$. If prominent signs of hypnosis were not apparent within $3 \mathrm{~s}$ of infusion the mouse was removed from the experiment (Brown et al., 2009).

Mice were conditioned using a two-lever procedure on a fixed ratio of one (FR1) schedule of reinforcement. Active lever presses were paired with a contingent light cue and all sessions were performed in the presence of a discriminative olfactory cue (vanilla essence) located beneath the active lever. Inactive lever responses had no effect.

Upon acquisition of stable responding [ $\geq 15$ drug rewards; (cocaine $0.5 \mathrm{mg} / \mathrm{kg} /$ infusion), $\geq 100$ rewards (sucrose $5 \mu \mathrm{l} 10 \% \mathrm{w} / \mathrm{v}$ ); $\geq 75 \%$ active lever discrimination over 3 consecutive days], motivation for selfadministration was assessed using a progressive ratio (PR) schedule of reinforcement as previously described (Brown et al., 2009; Cahir et al., 2011). Break point was defined as the last completed ratio within the session. Following evaluation of self-administration, mice were kept in their home cage for 3 weeks of abstinence before assessment of reward seeking during a $1 \mathrm{~h}$ extinction test in which drug cues were present, but no cocaine or sucrose was available.

Acute food deprivation stress-induced reinstatement of cocaine seeking. To examine the role of VTA CRFR1 in acute food deprivation stressinduced reinstatement another cohort of mice received either shCRFR1 $(n=11)$ or shControl virus $(n=11)$ in the VTA. Additionally, a third group of mice was injected with shCRFR1 virus in the lateral thalamus and served as a control to examine the anatomic specificity of the effects of CRFR1 knockdown $(n=7)$. Following $10 \mathrm{~d}$ of cocaine selfadministration, the mice underwent daily 30 min extinction sessions in which there was no cocaine delivery or light cue. Once mice met extinction criteria of $<50 \%$ of day 1 extinction lever pressing for 2 consecutive days, they were returned to the home cage and subject to a full $12 \mathrm{~h}$ dark-phase food-deprivation stress (Highfield, 2002), a CRF-dependent stressor (Shalev et al., 2006). Mice were then tested for reinstatement in the following dark phase, under extinction conditions.

Histological validation of injection sites. We confirmed the level and distribution of shRNA expression in each mouse by immunofluorescence for GFP. Mice were terminally anesthetized $(80 \mathrm{mg} / \mathrm{kg}, 0.1 \mathrm{ml} / 10 \mathrm{~g}$ pentobarbitone) and transcardially perfused. Brains were postfixed overnight in $4 \%$ paraformaldehyde and cryoprotected in $20 \%$ sucrose in PBS for $24 \mathrm{~h}$ before being frozen over liquid nitrogen in Tissue-TEK OCT (Sakura Finetek) and stored at $-80^{\circ} \mathrm{C}$.

Serial $40 \mu \mathrm{m}$ cryosections sampling the entire VTA were collected to assess viral injection site according to GFP expression. Sections were examined under fluorescence for GFP expression and every fourth section selected, and immunohistochemistry was performed to enable visualization of GFP expression using light microscopy. Sections were incubated overnight in rabbit anti-GFP (1:1000; Invitrogen) before incubation in biotinylated anti-rabbit secondary ( 2 h, 1:500; Vector Laboratories) and an avidin-biotin complex (1 h, 1:500; Vector Laboratories). All antigens were diluted in $0.1 \mathrm{M}$ PBS with $1 \%$ normal goal serum (Sigma) and $0.03 \%$ Triton $\mathrm{X}-100(\mathrm{BDH})$ and sections were washed with $0.1 \mathrm{~m}$ PBS between steps. The reaction product was visualized with nickel-enhanced 3,3'-diaminobenzidine (Sigma) in $0.01 \%$ hydrogen peroxide.

Viral injection sites for each animal included in the experiment are illustrated in Figures $2 B$ and $6 C$. A number of animals whose injection 
A

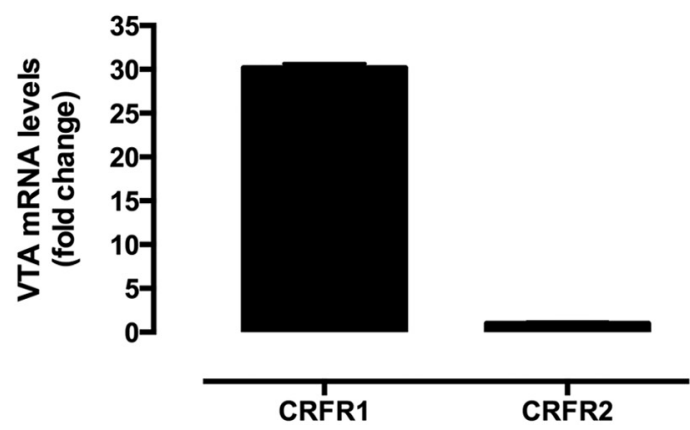

B

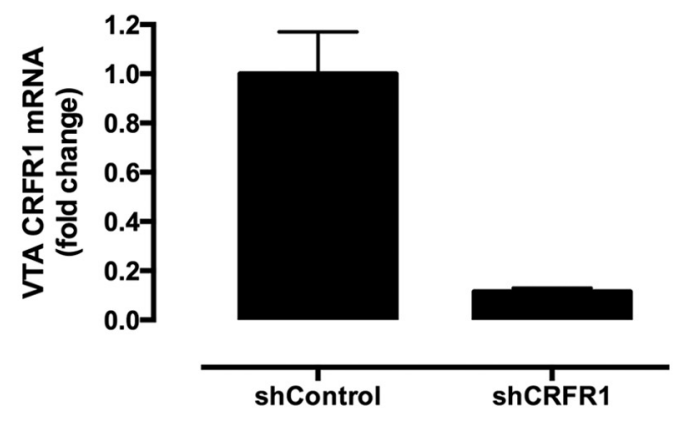

Figure 1. CRF receptor transcript levels in the VTA of naive and virus-treated mice. $A$, CRFR1 transcript levels were significantly greater than CRFR2 (equivalent to a 30 -fold difference) in the VTA of naive mice; $n=8$ mice ( 2 punches/mouse), $p<0.01$, Student's $t$ test. $B$, shCRFR1 significantly reduced CRFR1 mRNA levels in the VTA when compared with control virus (equivalent to a ninefold reduction); $n=6$ mice ( 2 punches/mouse), $p<0.01$, Student's $t$ test.
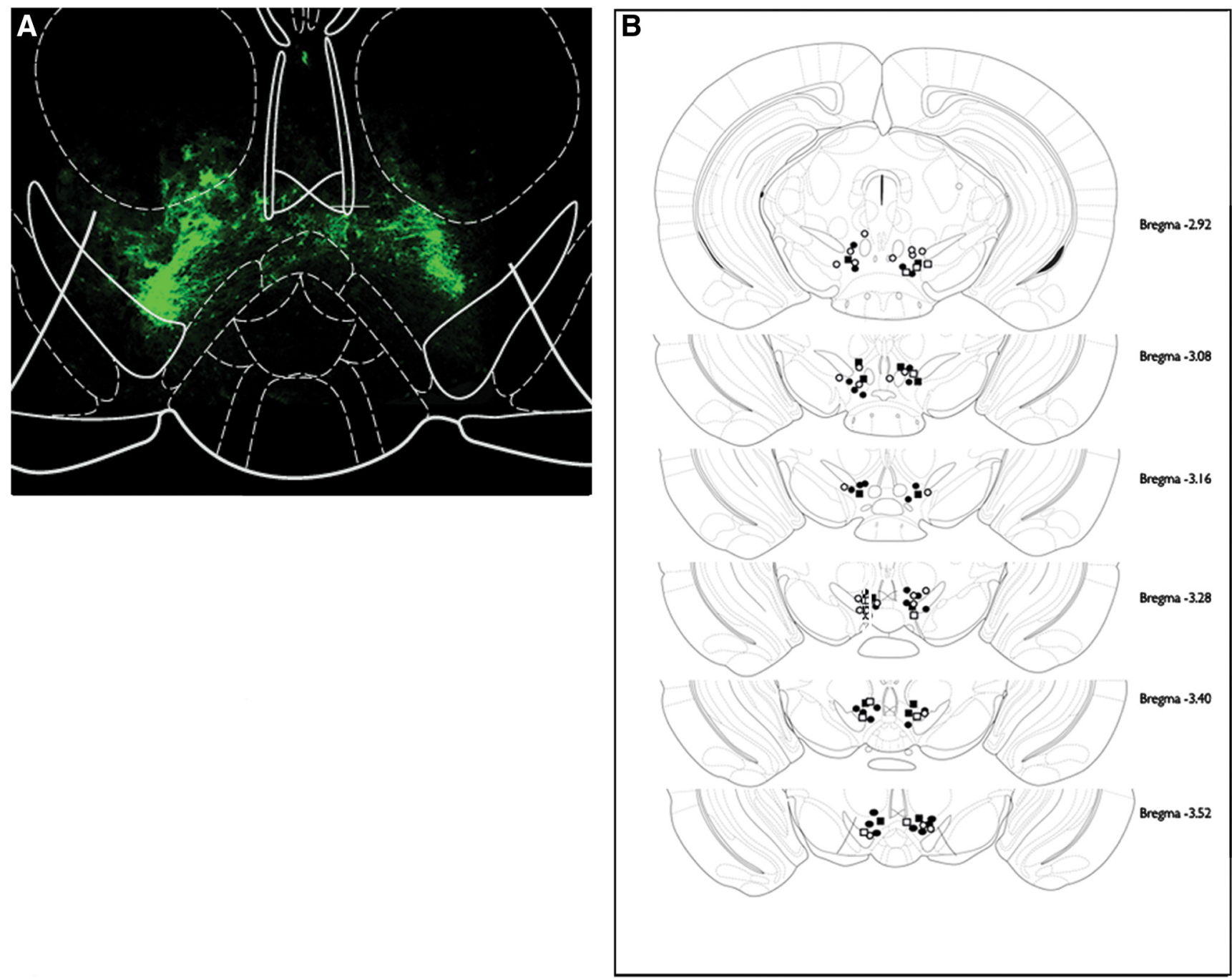

Figure 2. Illustration of injection sites confirming VTA-specific lentiviral transfection of mice in a cue-induced reward-seeking experiment. $A$, Representative immunofluorescent expression of GFP in the VTA. $\boldsymbol{B}$, Neuroanatomical representation of viral injection sites. Circles and squares represent location of shCRFR1 and control constructs, respectively, while open and closed represent sucrose and cocaine experiments. Adapted from Paxinos and Franklin, 2001.

sites fell outside the target area were excluded from the study (cocaine cue: shCRFR $1=3$; sucrose cue: shCRFR $1=3$, shControl $=1$; stress: shCRFR1 VTA $=1$, shControl VTA $=2$, shCRFR1 LT $=3$ ).

Statistical analysis. qPCR data were analyzed using Student's $t$ test. Behavioral data were analyzed retrospectively following assessment of
GFP-IR at injection sites by a reviewer blind to treatment group. All data were tested for normality (Kolmogorov-Smirnov) before assigning appropriate statistical tests. Self-administration and reward-seeking data were analyzed by two-way ANOVA with Student-NewmanKeuls post hoc comparisons to examine any significant main effects or 
A

FR1 sucrose self-administration

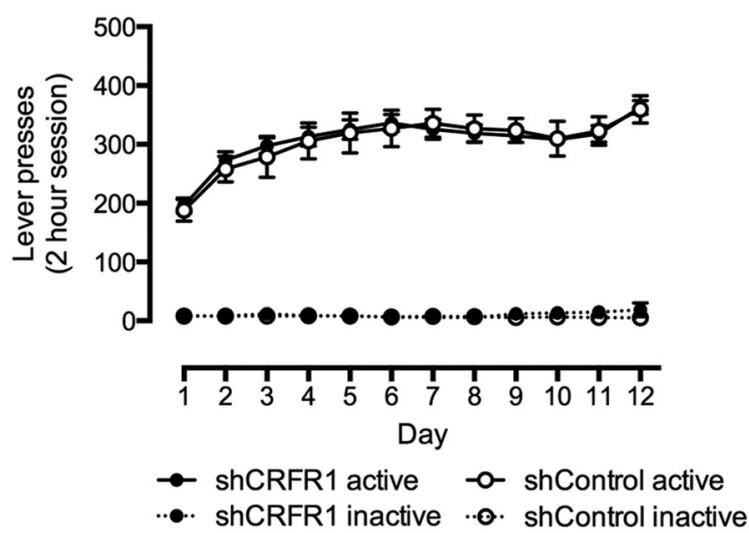

C

Progressive ratio responding

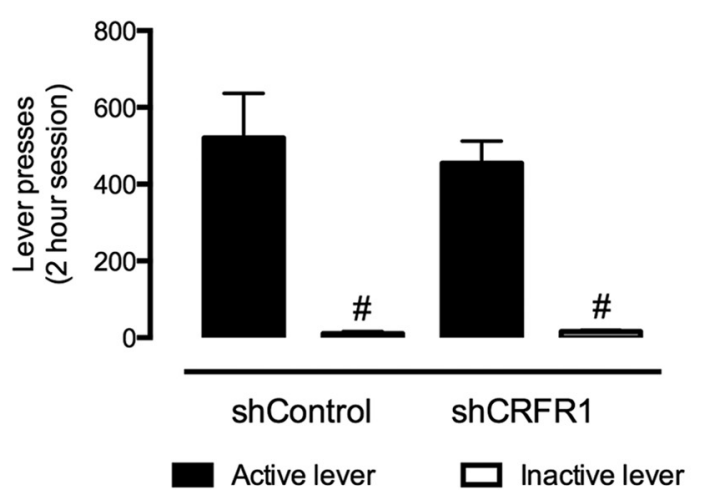

B

Average sucrose self-administration

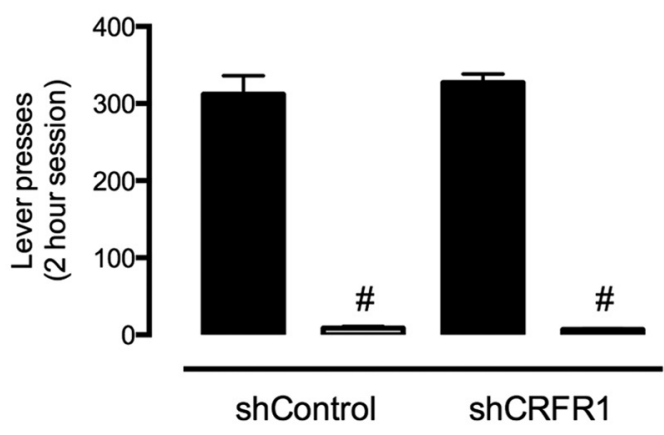

Active lever $\square$ Inactive lever

D

\section{Breakpoint}

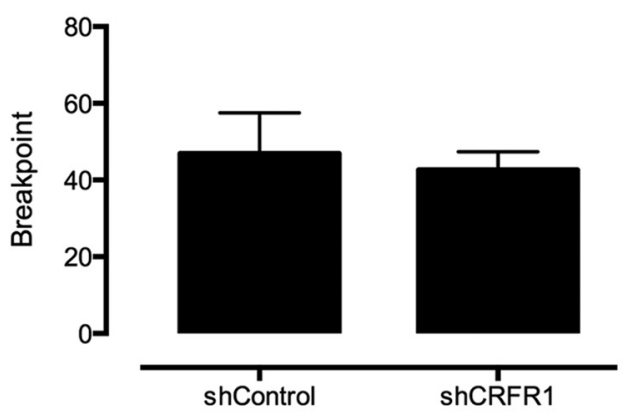

Figure 3. Effect of shCRFR1 viral injection in the VTA on sucrose self-administration on FR1 and PR schedules. $A$, No difference in sucrose self-administration was observed between shCRF-R1 and control viral-treated mice on an FR1 schedule. $\boldsymbol{B}, \boldsymbol{C}$, Both control and shCRF-R1 viral-treated mice responded significantly more for the active than the inactive lever on both FR1 (B) and PR ( () schedules; however, no differences were observed between the two treatment types. $\boldsymbol{D}$, Similarly, no difference was observed between the break point on a PR schedule between shCRF-R1 and control viral-treated mice. All data presented as mean $\pm \mathrm{SEM}, \# p<0.05$ active versus inactive lever responses. $\operatorname{shCRFR1,~} n=20 ;$ shControl, $n=9$.

interactions. Differences in break point on PR responding were assessed using a Mann-Whitney Rank Sum test. Significance was set at $p \leq 0.05$.

\section{Results}

Quantification of CRF receptor transcript levels in the VTA qPCR analysis of VTA tissue from naive mice showed significantly greater levels of CRFR1 mRNA compared withCRFR2, equivalent to a 30 -fold difference (Fig. 1A). This finding is consistent with in situ hybridization studies showing abundant expression of CRFR1 in the VTA, but little CRFR2 (Van Pett et al., 2000), although CRFR2 is measurable in the VTA by single-cell RT-PCR (Korotkova et al., 2006). Moreover, low transcript expression in and of itself should not be directly interpreted as a lack of functional CRFR2 receptors, since presynaptic receptors may still regulate VTA synaptic activity. Additionally, CRF has 10-fold higher affinity for CRFR1 than for CRFR2 (Dautzenberg et al., 2001). Given the prominence of CRFR1, we assessed the ability of a lenti-shCRFR1 virus to knockdown expression of CRFR1 mRNA in the VTA, and observed a ninefold decrease of CRFR1 mRNA compared with the control virus (Fig. 1B).
VTA CRFR1 knockdown has no effect on self-administration or motivation to self-administer sucrose or cocaine

No effect of VTA CRFR1 knockdown (Fig. 2) was observed on lever responding for sucrose $\left(F_{(1,23)}=0.027, p=0.87\right.$; Fig. $\left.3 A, B\right)$ or cocaine $\left(F_{(1,31)}=0.025, p=0.88\right.$; Fig. $\left.4 A, B\right)$ on an FR1 schedule of reinforcement. Similarly, no effect of intra-VTA lentisCRFR1 was observed on lever responding or break point on a PR schedule of reinforcement for sucrose (responding, $F_{(1,23)}=$ 0.025, $p=0.88$; break point, $U=67, p=0.98$; Fig. $3 C, D)$ or cocaine (responding, $F_{(1,31)}=0.025, p=0.88$; break point $U=$ 58, $p=0.66$; Fig. $4 C, D)$.

For all experiments mice demonstrated a significant preference for active over inactive lever responses (main effect of lever: sucrose: FR1 $F_{(1,23)}=654.08, p<0.0001, \mathrm{PR} F_{(1,23)}=62.08, p<$ 0.001 ; cocaine: $\operatorname{FR} 1 F_{(1,31)}=102.35, p<0.001, \mathrm{PR}_{(1,18)}=11.28$, $p<0.01)$.

VTA CRFR1 knockdown reduces cue-induced cocaine seeking, but not sucrose seeking

Following 3 weeks of abstinence, mice were assessed for the effect of VTA CRFR1 knockdown on cue-induced cocaine or sucrose 
A

FR1 cocaine self-administration

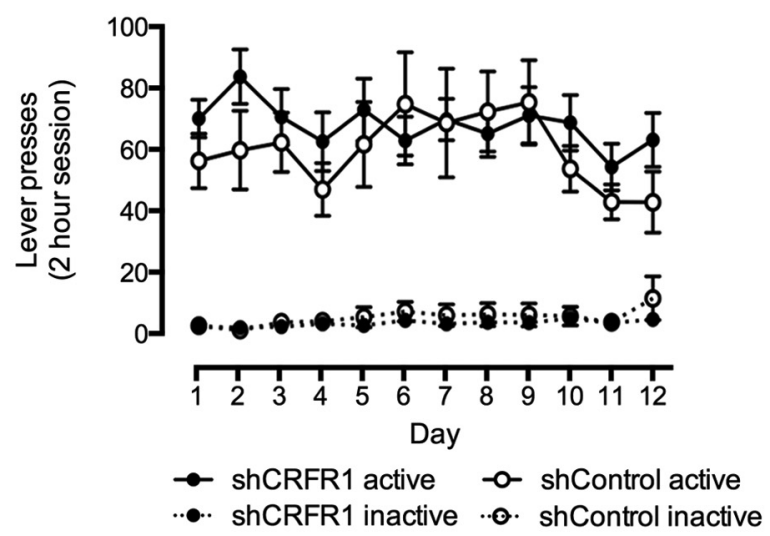

C

Progressive ratio responding

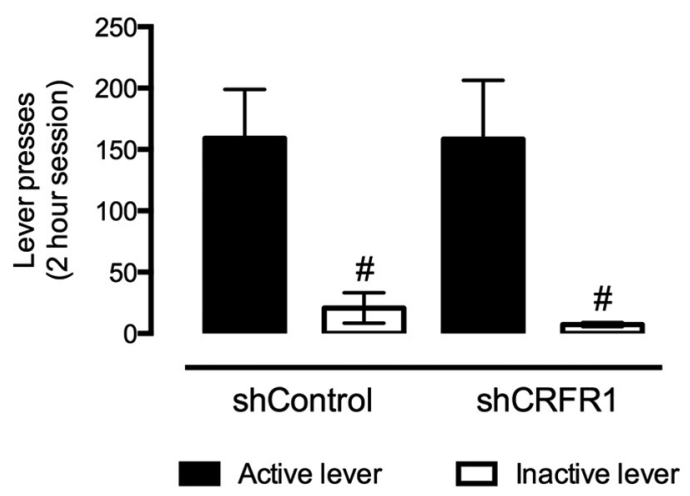

B

\section{Average cocaine self-administration}

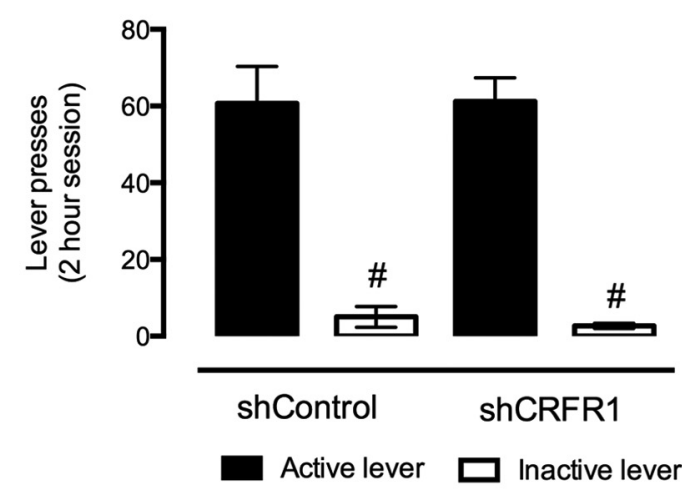

D

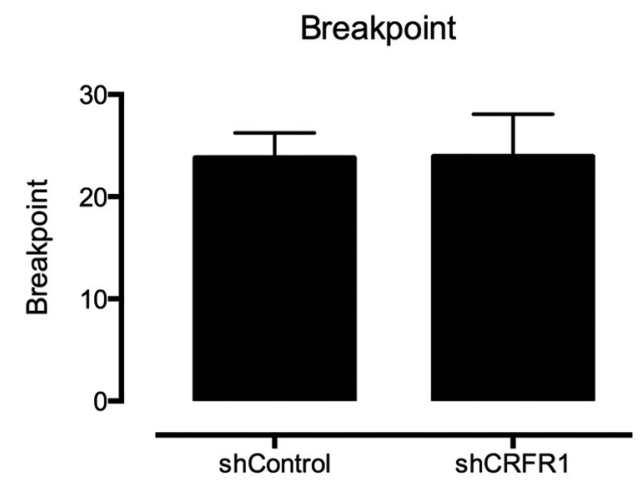

Figure 4. Effect of shCRFR1 viral injection in the VTA on cocaine self-administration on FR1 and PR schedules. $\boldsymbol{A}$, No differences were observed in cocaine self-administration (0.5 $\mathrm{mg} / \mathrm{kg}$ /infusion) on an FR1 schedule between shCRFR1 and control viral-treated mice. $\boldsymbol{B}, \boldsymbol{C}$, Both control and shCRF-R1 viral-treated mice responded significantly more for the active than the inactive lever on both FR1 $(\boldsymbol{B})$ and PR $(\boldsymbol{C})$ schedules, however, no differences were observed between the two treatment types. $\boldsymbol{D}$, Similarly, no difference was observed between the break point on a PR schedule between shCRF-R1 and control viral-treated mice. All data presented as mean \pm SEM, $\# p<0.05$ active versus inactive lever responses. shCRFR1, $n=27$; shControl, $n=10$.

seeking. While no effect was observed for sucrose seeking (treatment: $F_{(1,23)}=0.25, p=0.62$; lever: $F_{(1,23)}=88.24, p<0.001$; Fig. 5A), lenti-shCRFR1 treatment significantly reduced responding during cocaine seeking (effect of treatment: $F_{(1,32)}=9.8, p<0.01$; lever: $F_{(1,32)}=51.41, p<0.001$; interaction: $F_{(1,32)}=7.16, p<0.05$; Fig. $5 B$ ). Subsequent post hoc analysis of these effects revealed that those treated with shCRFR1 virus displayed significantly reduced responding for the active lever when compared with shControltreated mice $(p<0.001)$, while both groups demonstrated a significant preference for the active lever $(p<0.001)$.

CRFR1 knockdown in the VTA effectively blocks acute food deprivation stress-induced reinstatement of cocaine seeking Again, there was no effect of viral treatment (Fig. 6) on selfadministration of cocaine $\left(F_{(2,26)}=0.0334, p=0.96\right.$; Fig. $\left.7 A, B\right)$. There was also no observed effect on responding during extinction $\left(F_{(2,26)}=0.49, p=0.61\right.$; Fig. $\left.7 C\right)$; all mice had similar extinction bursts and extinguished to a similar level. Treatment groups also showed similar rates of extinction, as there was no effect of treatment on the number of days to reach extinction criteria (average of $6 \mathrm{~d}$, $F_{(2,25)}=0.078, p=0.85$; one-way ANOVA; Fig. $\left.7 D\right)$.

Acute food-deprivation stress reinstated lever pressing in both the control group receiving shControl virus in the VTA and the anatomic control group injected with lenti-shCRFR1 virus in the lateral thalamus. However, in VTA CRFR1 knockdown mice, there were no significant differences in lever pressing during the reinstatement session compared with extinction levels (Fig. 8). All mice showed high discrimination for the active over inactive lever (shControl VTA: $79 \pm 8 \%$; shCRFR1 VTA: $75 \pm 6 \%$; shCRFR1 LT: $85 \pm 10 \%)$. A two-way repeated-measures ANOVA examining the effects of treatment and day (extinction vs reinstatement) on the number of active lever presses showed a significant treatment $\times$ day interaction $\left(F_{(2,26)}=5.80, p=\right.$ 0.0083). Post hoc testing showed that active lever responding on reinstatement was significantly greater in shControl VTA and shCRFR1 LT groups ( $p<0.001$ for both), but no differences were noted between extinction and reinstatement in the shCRFR1 VTA group ( $p<0.05)$. Thus, knockdown of CRFR1 in the VTA was sufficient to prevent acute food deprivation stressinduced reinstatement of cocaine seeking.

\section{Discussion}

CRFR1 receptors in the VTA do not critically contribute to self-administration of cocaine

Our data suggest that, at least within the VTA, CRFR1 receptors are not critically involved in mediating cocaine self-administration un- 


\section{A}

\section{cue-induced sucrose seeking}

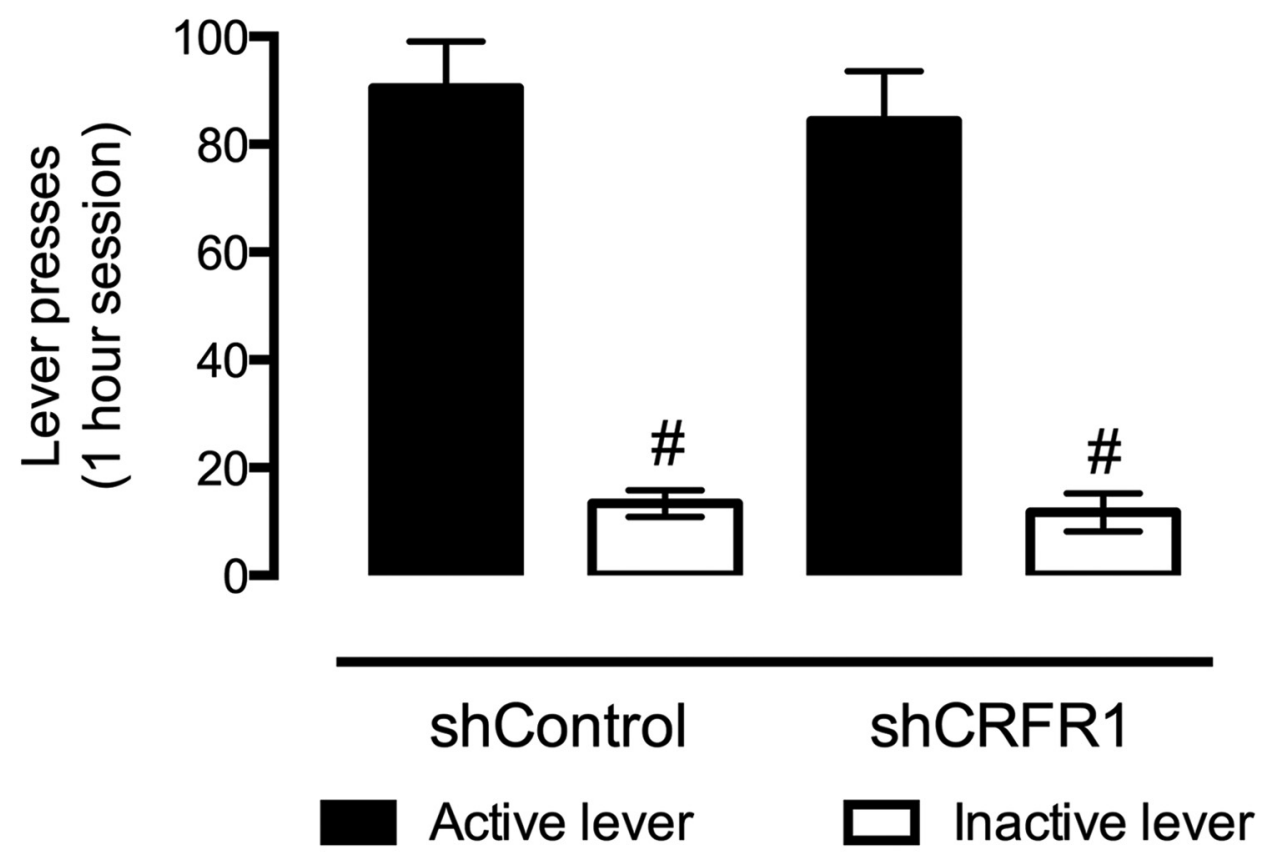

B

\section{cue-induced cocaine seeking}

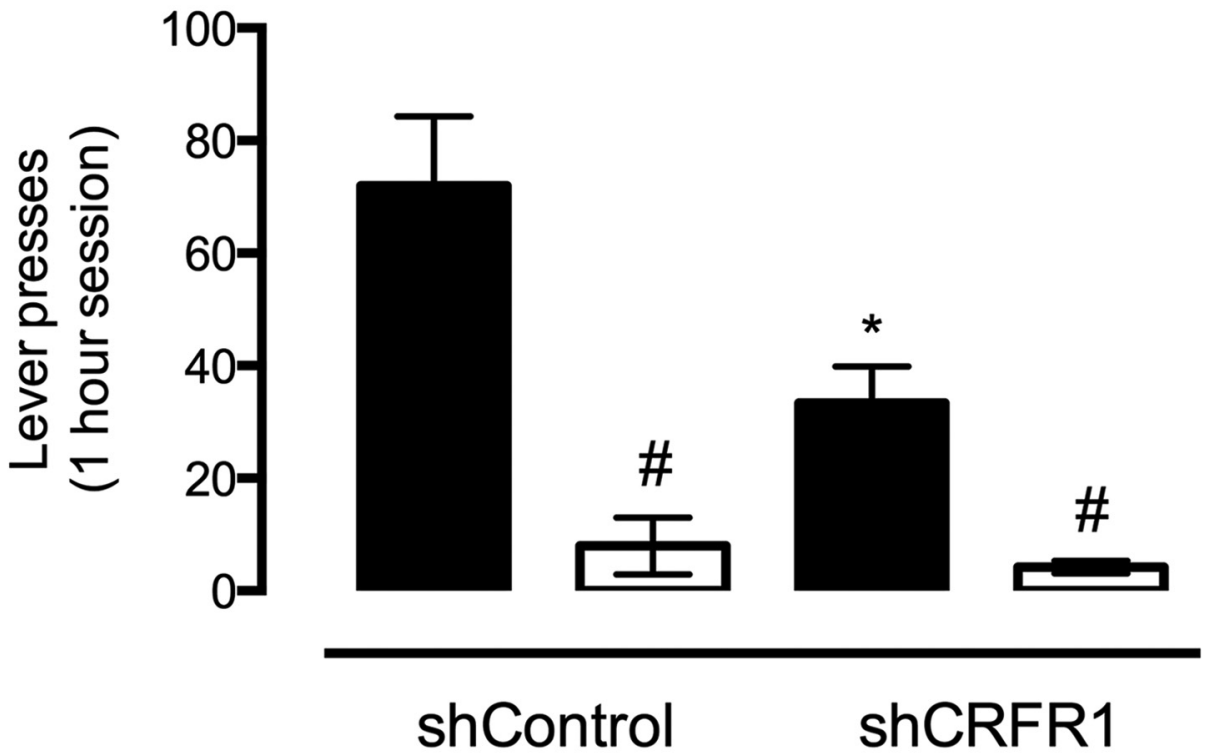

Active lever

$\square$ Inactive lever

Figure 5. Effect of VTA-directed shCRFR1 viral transfection on cue-induced sucrose and cocaine seeking. $A$, While both shCRFR1 and control viral-treated mice responded significantly more for the active than inactive lever during cue-induced sucrose seeking, no differences were observed between the two treatments. B, VTA directed shCRF-R1 transfection, however, significantly reduced responding for the active lever during cue-induced cocaine seeking, while maintaining the preference for active over inactive lever responses in both treatment types. All data presented as mean \pm SEM, $\# p<0.05$ active versus inactive lever responses; ${ }^{*} p<0.05$ control versus shCRFR1. Sucrose: shCRFR1, $n=20$; shControl, $n=9$; cocaine: shCRFR1, $n=27$; shControl, $n=10$.

der a short access operant paradigm, as no effect of CRFR1 knockdown was observed on FR1 or PR schedules of reinforcement. This concurs with studies that found no effect of systemic CRFR1 antagonism on self-administration and/or motivation for cocaine under restricted access conditions ( Przegaliński et al., 2005; Mello et al., 2006; Boyson et al., 2011); but note in contrast, Goeders and Guerin (2000). While it is possible that CRFR1 may exert an influence on cocaine self-administration through other 

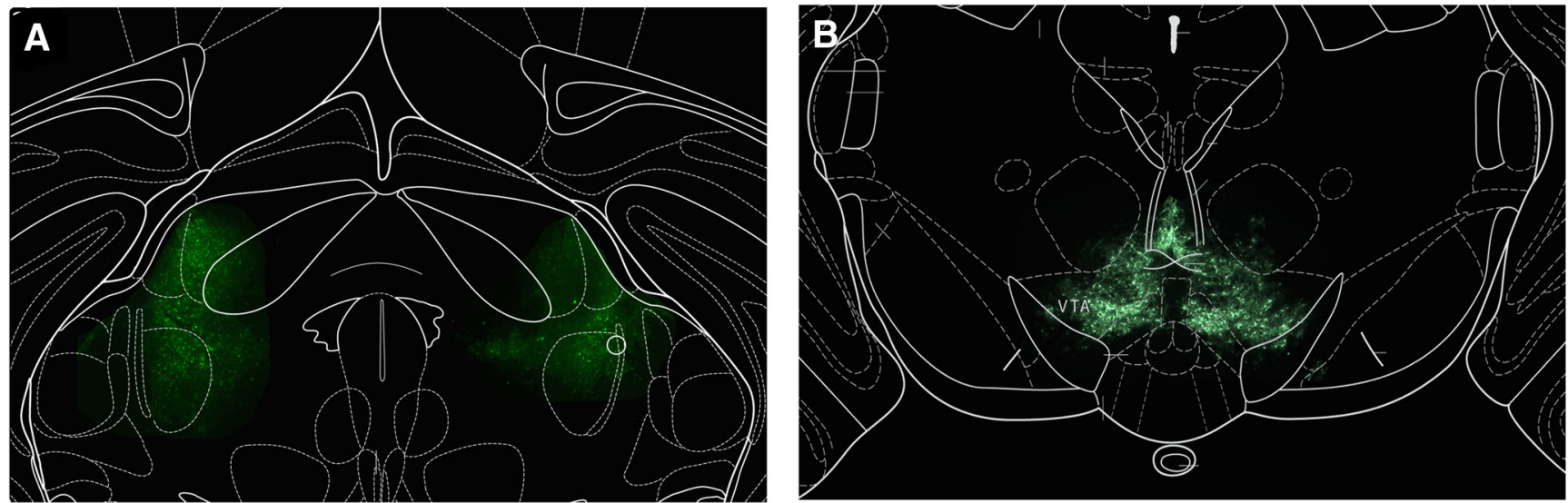

C
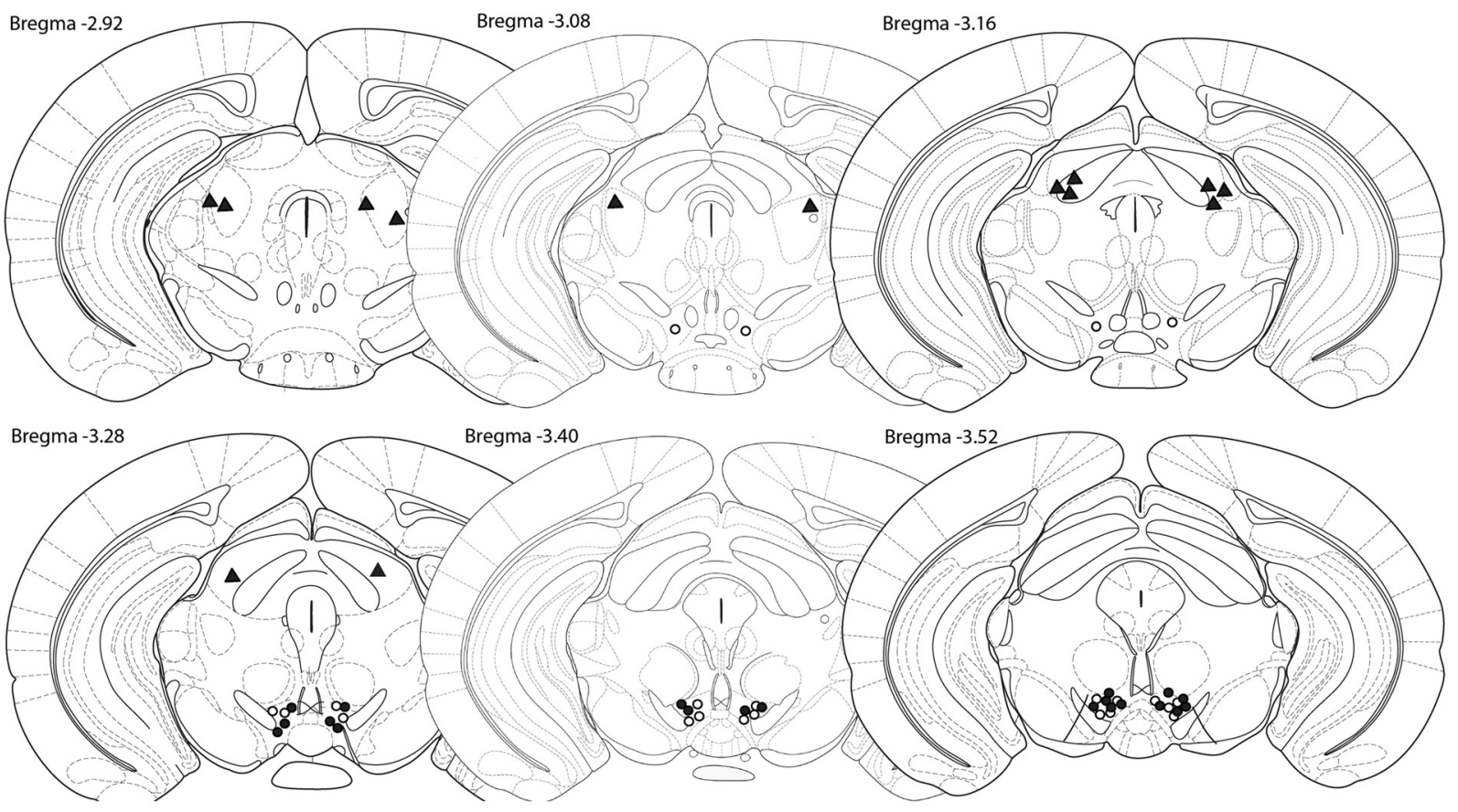

Figure 6. Illustration of injection sites confirming VTA-specific lentiviral transfection of mice included in stress-induced reinstatement experiment. $A$, Representative expression of GFP in the VTA and lateral thalamus $(\boldsymbol{B})$. $\boldsymbol{C}$, Neuroanatomical representation of viral injection sites. Open and closed circles represent intra-VTA injection sites of control and shCRFR1 virus, respectively. Triangles represent injection sites of shCRFR1 virus targeting the lateral thalamus. Adapted from Paxinos and Franklin, 2001.

brain nuclei, this may be dependent upon the level of cocaine exposure (Specio et al., 2008) and stress (Boyson et al., 2011). A similar effect has also been observed for other drugs of abuse. CRFR1 antagonists typically only reduce ethanol self-administration in rats made dependent (Funk et al., 2007) and/or with elevated stress levels (Lodge and Lawrence, 2003), and in certain alcoholpreferring strains (Gehlert et al., 2007), a phenomenon suggested to involve dysregulation of the CRF system. Indeed, extended access to cocaine can cross-sensitize locomotor responses to CRF (Erb et al., 2003) and alter levels of CRF differentially within the brain when compared with animals administering cocaine on a short access paradigm (Zorrilla et al., 2012). Chronic stress may also alter brain CRF and CRFR1 levels (Bonaz and Rivest, 1998; Sutherland et al., 2010). It is therefore possible that the schedule of cocaine access/level of stress experienced by the mice in our study did not alter CRF levels sufficiently to recruit an action of VTA CRFR1 in cocaine intake.
CRF1 receptors within the VTA are necessary for stressinduced reinstatement of cocaine seeking

The role of VTA CRF in mediating stress-induced reinstatement of cocaine seeking is well established. Wang et al. (2007) reported that intra-VTA perfusion of CRFR2 but not CRFR1 antagonists prevented stress-induced reinstatement of cocaine seeking in rats. Conversely, using direct intra-VTA microinjections Blacktop et al. (2011) found that only CRFR1, and not CRFR2, antagonists prevented stress-induced cocaine seeking. The reason for the discrepancy is unclear, but may relate to differences in the method of delivery (reverse dialysis vs microinjection), potential off-target effects of some of the drugs (Zorrilla et al., 2013), and differences in cocaine intake.

Here we show that CRFR1 knockdown in the VTA prevented stress-induced reinstatement of cocaine seeking independent of differences in self-administration or extinction behavior. Moreover, control virus within the VTA and targeted lenti-shCRFR1 
A

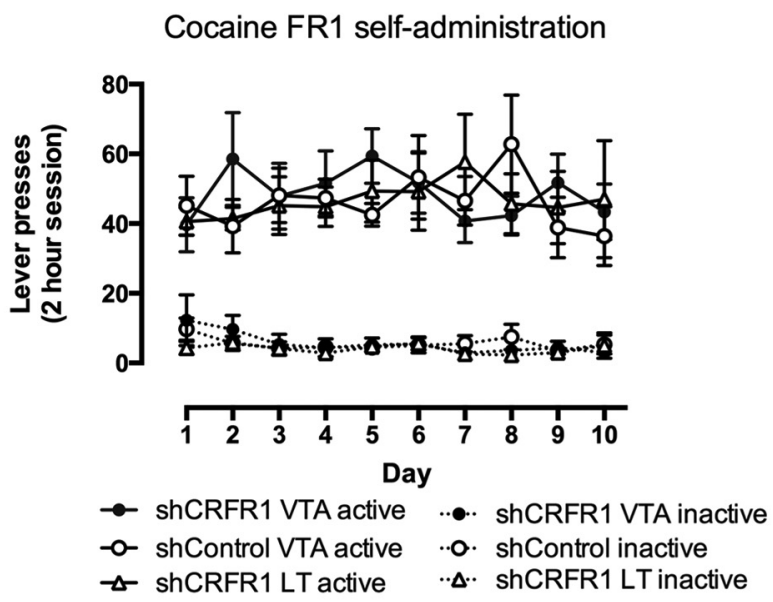

C

Extinction training

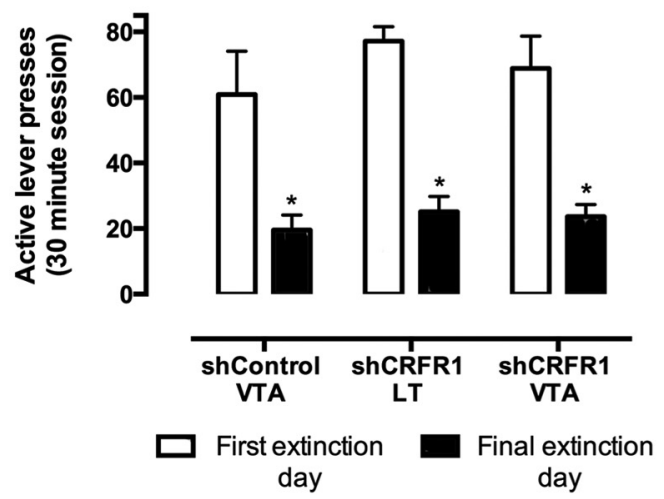

B

Average cocaine self-administration

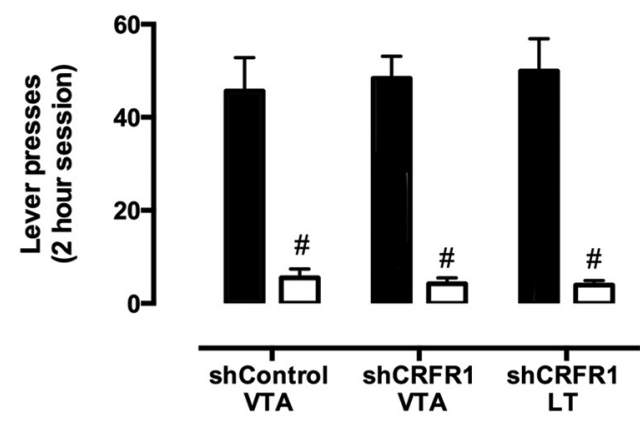

Active lever $\square$ Inactive lever

D

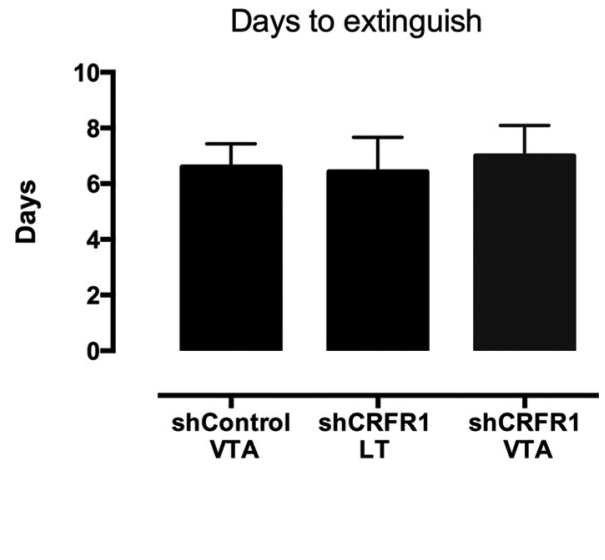

Figure 7. Effect of CRFR1 knockdown in the VTA on extinction of cocaine self-administration. $\boldsymbol{A}$, No differences in cocaine self-administration were observed between treatment groups. $\boldsymbol{B}$, Mice made significantly fewer lever presses on the final day of extinction compared with extinction day 1 across all treatment groups ( $\left.{ }^{*} p<0.05\right)$. However, no differences were observed between treatment groups on either day 1 or the final day of extinction ( $\boldsymbol{C}$, nor were there differences in the number of days required to reach extinction criteria $(\boldsymbol{D})$. All data presented as mean \pm SEM, \#p $<$ 0.05 active versus inactive lever responses; ${ }^{*} p<0.05$ first versus final extinction session. shControl VTA, $n=11 ; \operatorname{shCRFR1~LT,~} n=7 ;$ shCRFR1 VTA, $n=11$.

infusion outside the VTA both had no such effect, suggesting anatomic specificity of this effect. This supports a critical role of CRFR1 signaling in the VTA in stress-induced reinstatement of cocaine seeking.

\section{CRFR1 receptors within the VTA contribute to cue-induced cocaine seeking}

To address the role of VTA CRFR1 in stress-induced reinstatement we used an extinction-reinstatement model of relapse. This model has been used extensively, however, is associated with certain limitations. Extinction is an active process where rodents learn to inhibit active lever responding in response to devaluation of this behavior in the absence of drug reward. Although extinction procedures are sometimes used clinically, the majority of individuals with substance use disorders do not enter formal rehabilitation (Substance Abuse and Mental Health Services Administration 2010). Whether by incarceration, hospitalization, or self-imposed, dependent individuals can remain abstinent for extended periods of time before relapsing. An alternative model measuring drug seeking after an extended period of enforced abstinence, away from the drug-taking environment, may better reflect the human experience of enduring propensity to relapse.
Using this paradigm, we observed that knockdown of CRFR1 in the VTA significantly attenuated cue-induced cocaine seeking. These findings are consistent with previous data demonstrating a reduction in cue-induced reinstatement of cocaine seeking following systemic administration of the CRFR1 antagonist CP154,526 (Goeders and Clampitt, 2002), and provide evidence for a role for CRFR1 in the VTA in cue-induced cocaine seeking. Further, these data also suggest a dissociation between the contribution of CRFR1 in the VTA to primary versus secondary reinforcement, consonant with a previous study demonstrating dose-dependent reductions of drug-primed reinstatement by systemic CRFR1 antagonism, independent of any effects on cocaine self-administration (Przegaliński et al., 2005).

There is increasing evidence for a role for CRF in cue conditioning and salience attribution. Salient visual, olfactory, and auditory cue exposure increases levels of CRF in the prefrontal cortex (Merali et al., 2004) and central amygdala (Merali et al., 2003), while CRF antagonists reduce conditioned anxiety elicited from cocaine-related cue exposure (DeVries and Pert, 1998) and hypothalamic pituitary adrenal axis activation (DeVries et al., 1998). It is possible these effects are driven by actions at CRFR1, as expression of fear-potentiated startle is disrupted in mice lacking CRFR1 (Risbrough et al., 2009). Beyond a role in condition- 


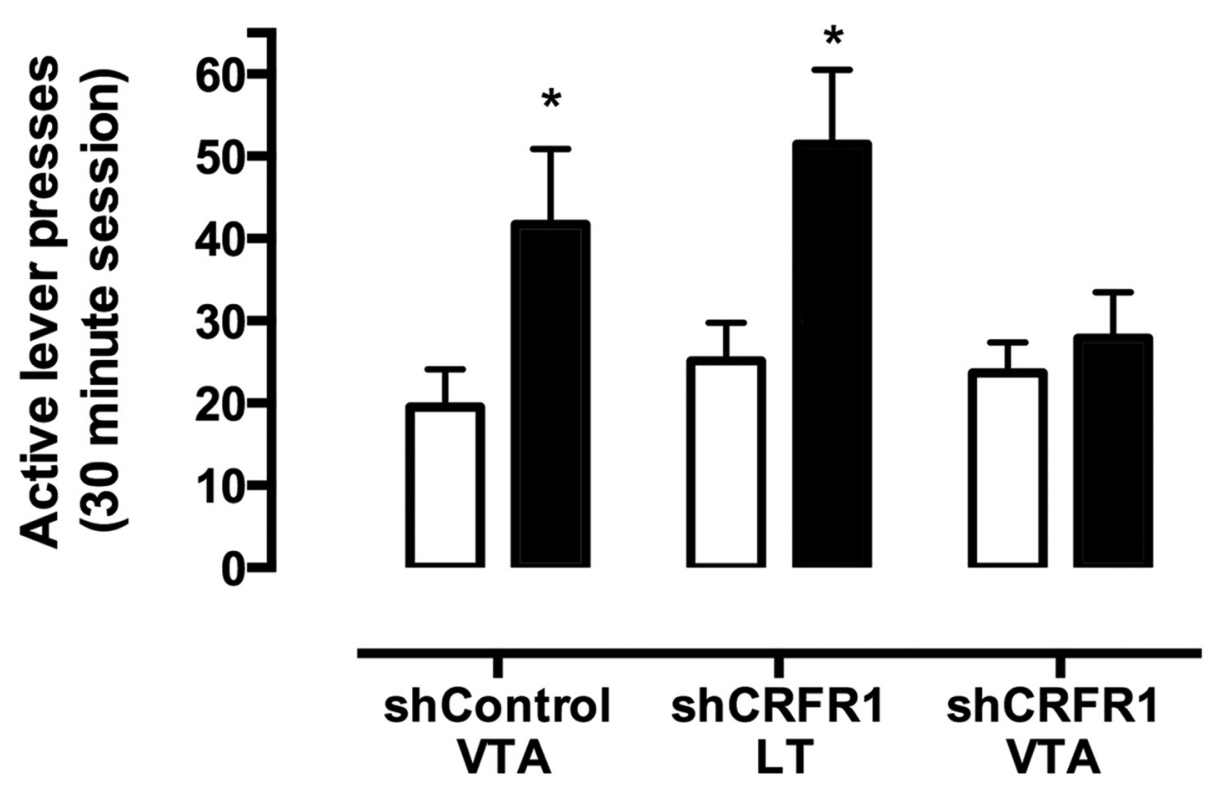

$\square$ Extinction $\square$ Reinstatement

Figure 8. Stress-induced reinstatement of cocaine seeking. Acute food deprivation reinstated cocaine seeking in the control virus-treated group and mice injected in the lateral thalamus $\left({ }^{*} p<\right.$ 0.05), but not intra-VTA shCRFR1-treated mice. Data presented as mean $\pm \mathrm{SEM},{ }^{*} p<0.05$ final extinction session versus reinstatement. shControl VTA, $n=11$; shCRFR1 LT, $n=7$; shCRFR1 VTA, $n=11$.

ing, CRF has also been implicated in the attribution of incentive salience to reward-related cues in a pavlovian-instrumental transfer paradigm (Peciña et al., 2006). The VTA has also been implicated in mediating both cue conditioning (Lee et al., 2011) and incentive salience (Corbit et al., 2007), particularly via connections with the central amygdala. Together, these findings and those of the current study suggest that targeting CRFR1 within the VTA may reduce cue-induced cocaine seeking by disrupting the secondary reinforcement of and/or attribution of incentive salience to cocaine-related cues, beyond generalized effects of cue exposure on stress. A possible source of CRF to drive both stressand cue-induced cocaine seeking is the ventral bed nucleus of the stria terminals (BNST). The BNST sends dense CRF-containing projections to the VTA, and is selectively activated during cueand stress-induced reinstatement in rats (Erb et al., 1999; Rodaros et al., 2007; Mahler and Aston-Jones, 2012). Undoubtedly, future studies will identify the source(s) of CRF input to the VTA implicated in relapse-like drug seeking.

CRFR1 receptors within the VTA are not critical for selfadministration of sucrose or cue-induced sucrose seeking The lack of impact on sucrose-related behaviors confirms the effects of VTA CRFR1 knockdown are not attributable to motor impairment, suggests that CRF action in the VTA during cueinduced "relapse" is specific to drug seeking, and does not generalize to natural rewards. While CRFR1 knock-out and antagonist studies have previously shown no effect on binge consumption of sucrose (Sparta et al., 2008; Kaur et al., 2012), there is evidence for a role of CRFR1 in stress-induced reinstatement of food seeking (Ghitza et al., 2006) and the integration of natural reward-related cues (Peciña et al., 2006). While this finding suggests CRF may act via different receptors or anatomic loci for natural rewards than for cocaine, the discrepancy may be due to the differential effect of sucrose and cocaine on VTA signaling. Though both sucrose and cocaine self-administration result in the potentiation of glu- tamatergic synapses onto VTA DA neurons, sucrose selfadministration produces only transient potentiation, which dissipates within a 3 week period of abstinence, while cocaineinduced LTP is persistent (Chen et al., 2008). Furthermore, the ability of VTA CRF to control local glutamate release and consequent dopaminergic activation is dependent on CRFR1; however, it is only found in animals with a previous history of cocaine exposure (Hahn et al., 2009). In this way neuroadaptations within the CRF system induced by cocaine exposure, particularly within the VTA, may explain how cocaine-related cues attain greater motivational salience when compared with food-related cues. In this regard, our collective data also suggest that VTA CRFR1 appears possibly more implicated in cue-driven, as opposed to context-driven, cocaine seeking. Thus, in our "stress experiment" there was no effect of VTA CRFR1 knockdown on active extinction performed in the absence of cues paired with drug availability, yet in our "cue experiment" we saw marked reduction of cue-induced cocaine seeking after abstinence in the same drug context. More studies are clearly required to disentangle this question.

\section{Conclusion}

Our study indicates a role for CRF within the VTA, acting via CRFR1, in stress-induced reinstatement, as well as cue-induced cocaine seeking, independent of effects on cocaine or sucrose self-administration. It also suggests that regardless of the form of abstinence ( \pm extinction), both cue- and stress-induced drug seeking involves CRFR1 in the VTA. While presynaptic CRFRs can modulate excitatory input onto dopaminergic VTA cells (Wang et al., 2007), CRFR1 on the terminals of afferent glutamatergic projections are unlikely to be responsible for the effects we observed. Given the knockdown approach used, it is more likely that cocaine seeking was modulated by CRFR1 expressed on cell bodies and dendritic processes of neurons intrinsic to the VTA, including dopaminergic VTA neurons (Refojo et al., 2011). Nev- 
ertheless, we cannot rule out potential involvement of CRFR1 expressed on distal projections of VTA neurons; for example, CRFR1 is present on dopaminergic terminals in the nucleus accumbens (Lemos et al., 2012).

Psychological stress and exposure to drug-associated cues are major factors that promote craving and relapse in humans and are difficult to avoid in daily life (O'Brien et al., 1992; Brown et al., 1995; Sinha, 2001). Given that the underlying circuitry of stressand cue-driven drug seeking is overlapping to some degree, targeting these concurrences is an important goal for effective treatment (Shaham et al., 2003).

\section{References}

Blacktop JM, Seubert C, Baker DA, Ferda N, Lee G, Graf EN, Mantsch JR (2011) Augmented cocaine seeking in response to stress or CRF delivered into the ventral tegmental area following long-access self-administration is mediated by CRF receptor type 1 but not CRF receptor type 2. J Neurosci 31:11396-11403. CrossRef Medline

Bonaz B, Rivest S (1998) Effect of a chronic stress on CRF neuronal activity and expression of its type 1 receptor in the rat brain. Am J Physiol 275: R1438-R1449. Medline

Bossert JM, Marchant NJ, Calu DJ, Shaham Y (2013) The reinstatement model of drug relapse: recent neurobiological findings, emerging research topics, and translational research. Psychopharmacology 229:453-476. CrossRef Medline

Boyson CO, Miguel TT, Quadros IM, Debold JF, Miczek KA (2011) Prevention of social stress-escalated cocaine self-administration by CRF-R1 antagonist in the rat VTA. Psychopharmacology 218:257-269. CrossRef Medline

Brown PJ, Recupero PR, Stout R (1995) PTSD substance abuse comorbidity and treatment utilization. Addict Behav 20:251-254. CrossRef Medline

Brown RM, Short JL, Cowen MS, Ledent C, Lawrence AJ (2009) A differential role for the adenosine $\mathrm{A} 2 \mathrm{~A}$ receptor in opiate reinforcement vs opiateseeking behavior. Neuropsychopharmacology 34:844-856. CrossRef Medline

Cahir E, Pillidge K, Drago J, Lawrence AJ (2011) The necessity of $\alpha 4^{\star}$ nicotinic receptors in nicotine-driven behaviors: dissociation between reinforcing and motor effects of nicotine. Neuropsychopharmacology 36: 1505-1517. CrossRef Medline

Chen BT, Bowers MS, Martin M, Hopf FW, Guillory AM, Carelli RM, Chou JK, Bonci A (2008) Cocaine but not natural reward self-administration nor passive cocaine infusion produces persistent LTP in the VTA. Neuron 59:288-297. CrossRef Medline

Corbit LH, Janak PH, Balleine BW (2007) General and outcome-specific forms of Pavlovian-instrumental transfer: the effect of shifts in motivational state and inactivation of the ventral tegmental area. Eur J Neurosci 26:3141-3149. CrossRef Medline

Dautzenberg FM, Py-Lang G, Higelin J, Fischer C, Wright MB, Huber G (2001) Different binding modes of amphibian and human corticotropin-releasing factor type 1 and type 2 receptors: evidence for evolutionary differences. J Pharmacol Exp Ther 296:113-120. Medline

DeVries AC, Pert A (1998) Conditioned increases in anxiogenic-like behavior following exposure to contextual stimuli associated with cocaine are mediated by corticotropin-releasing factor. Psychopharmacology 137: 333-340. CrossRef Medline

DeVries AC, Taymans SE, Sundstrom JM, Pert A (1998) Conditioned release of corticosterone by contextual stimuli associated with cocaine is mediated by corticotropin-releasing factor. Brain Res 786:39-46. CrossRef Medline

Erb S, Stewart J (1999) A role for the bed nucleus of the stria terminalis, but not the amygdala, in the effects of corticotropin-releasing factor on stressinduced reinstatement of cocaine seeking. J Neurosci 19:RC35. Medline

Erb S, Funk D, Lê AD (2003) Prior, repeated exposure to cocaine potentiates locomotor responsivity to central injections of corticotropin-releasing factor (CRF) in rats. Psychopharmacology 170:383-389. CrossRef Medline

Feltenstein MW, See RE (2008) The neurocircuitry of addiction: an overview. Br J Pharmacol 154:261-274. CrossRef Medline

Funk CK, Zorrilla EP, Lee MJ, Rice KC, Koob GF (2007) Corticotropinreleasing factor 1 antagonists selectively reduce ethanol self-administration in ethanol-dependent rats. Biol Psychiatry 61:78-86. CrossRef Medline

Gehlert DR, Cippitelli A, Thorsell A, Lê AD, Hipskind PA, Hamdouchi C,
Lu J, Hembre EJ, Cramer J, Song M, McKinzie D, Morin M, Ciccocioppo R, Heilig M (2007) 3-(4-Chloro-2-morpholin-4-yl-thiazol-5yl)-8-(1-ethylpropyl)-2,6-dimethyl-imidazo [1,2-b]pyridazine: a novel brain-penetrant, orally available corticotropin-releasing factor receptor 1 antagonist with efficacy in animal models of alcoholism. J Neurosci 27 : 2718-2726. CrossRef Medline

Ghitza UE, Gray SM, Epstein DH, Rice KC, Shaham Y (2006) The anxiogenic drug yohimbine reinstates palatable food seeking in a rat relapse model: a role of CRF1 receptors. Neuropsychopharmacology 31:21882196. Medline

Goeders NE, Clampitt DM (2002) Potential role for the hypothalamopituitary-adrenal axis in the conditioned reinforcer-induced reinstatement of extinguished cocaine seeking in rats. Psychopharmacology 161: 222-232. CrossRef Medline

Goeders NE, Guerin GF (2000) Effects of the CRH receptor antagonist CP154,526 on intravenous cocaine self-administration in rats. Neuropsychopharmacology 23:577-586. CrossRef Medline

Hahn J, Hopf FW, Bonci A (2009) Chronic cocaine enhances corticotropinreleasing factor-dependent potentiation of excitatory transmission in ventral tegmental area dopamine neurons. J Neurosci 29:6535-6544. CrossRef Medline

Highfield DA, Mead AN, Grimm JW, Rocha BA, Shaham Y (2002) Reinstatement of cocaine seeking in 129X1/Svj mice: effects of cocaine priming, cocaine cues and food deprivation. Psychopharmacology 161:417-424. CrossRef Medline

Kaur S, Li J, Stenzel-Poore MP, Ryabinin AE (2012) Corticotropin-releasing factor acting on corticotropin-releasing factor receptor type 1 is critical for binge alcohol drinking in mice. Alcohol Clin Exp Res 36:369-376. CrossRef Medline

Korotkova TM, Brown RE, Sergeeva OA, Ponomarenko AA, Haas HL (2006) Effects of arousal- and feeding-related neuropeptides on dopaminergic and GABAergic neurons in the ventral tegmental area of the rat. Eur J Neurosci 23:2677-2685. CrossRef Medline

Lee HJ, Wheeler DS, Holland PC (2011) Interactions between amygdala central nucleus and the ventral tegmental area in the acquisition of conditioned cue-directed behavior in rats. Eur J Neurosci 33:1876-1884. CrossRef Medline

Lemos JC, Wanat MJ, Smith JS, Reyes BA, Hollon NG, Van Bockstaele EJ, Chavkin C, Phillips PE (2012) Severe stress switches CRF action in the nucleus accumbens from appetitive to aversive. Nature 490:402-406. Medline

Lodge DJ, Lawrence AJ (2003) The effect of isolation rearing on volitional ethanol consumption and central CCK/dopamine systems in FawnHooded rats. Behav Brain Res 141:113-122. CrossRef Medline

Mahler SV, Aston-Jones GS (2012) Fos activation of selective afferents to the ventral tegmental area during cue-induced reinstatement of cocaine seeking in rats. J Neurosci 32:13309-13326. CrossRef Medline

McFarland K, Davidge SB, Lapish CC, Kalivas PW (2004) Limbic and motor circuitry underlying footshock-induced reinstatement of cocaine-seeking behaviour. J Neurosci 24:1551-1560. CrossRef Medline

McLellan AT, Lewis DC, O'Brien CP, Kleber HD (2000) Drug dependence, a chronic medical illness: implications for treatment, insurance, and outcomes evaluation. JAMA 284:1689-1695. CrossRef Medline

McPherson CS, Mantamadiotis T, Tan SS, Lawrence AJ (2010) Deletion of CREB1 from the dorsal telencephalon reduces motivational properties of cocaine. Cereb Cortex 20:941-952. CrossRef Medline

Mello NK, Negus SS, Rice KC, Mendelson JH (2006) Effects of the CRF1 antagonist antalarmin on cocaine self-administration and discrimination in rhesus monkeys. Pharmacol Biochem Behav 85:744-751. CrossRef Medline

Merali Z, Michaud D, McIntosh J, Kent P, Anisman H (2003) Differential involvement of amygdaloid CRH system(s) in the salience and valence of the stimuli. Prog Neuropsychopharmacol Biol Psychiatry 27:1201-1212. CrossRef Medline

Merali Z, McIntosh J, Anisman H (2004) Anticipatory cues differentially provoke in vivo peptidergic and monoaminergic release at the medial prefrontal cortex. Neuropsychopharmacology 29:1409-1418. CrossRef Medline

Moffett MC, Goeders NE (2007) CP-154526 a CRF type-1 receptor antagonist, attenuates the cue- and methamphetamine-induced reinstatement of extinguished methamphetamine-seeking behaviour in rats. Psychopharmacology 190:171-180. Medline 
O’Brien CP (1997) A range of research-based pharmacotherapies for addiction. Science 278:66-70. CrossRef Medline

O’Brien CP, Childress AR, McLellan AT, Ehrman R (1992) Classical conditioning in drug-dependent humans. Ann N Y Acad Sci 654:400-415. CrossRef Medline

Paxinos G, Franklin K (2001) The mouse brain in stereotaxic coordinates, Ed 2. San Diego: Academic.

Peciña S, Schulkin J, Berridge KC (2006) Nucleus accumbens corticotropinreleasing factor increases cue-triggered motivation for sucrose reward: paradoxical positive incentive effects in stress? BMC Biol 4:8. CrossRef Medline

Przegaliński E, Filip M, Frankowska M, Zaniewska M, Papla I (2005) Effects of CP 154,526, a CRF1 receptor antagonist, on behavioral responses to cocaine in rats. Neuropeptides 39:525-533. CrossRef Medline

Refojo D, Schweizer M, Kuehne C, Ehrenberg S, Thoeringer C, Vogl AM, Dedic N, Schumacher M, von Wolff G, Avrabos C, Touma C, Engblom D, Schütz G, Nave KA, Eder M, Wotjak CT, Sillaber I, Holsboer F, Wurst W, Deussing JM (2011) Glutamatergic and dopaminergic neurons mediate anxiogenic and anxiolytic effects of CRHR1. Science 333:1903-1907. CrossRef Medline

Risbrough VB, Geyer MA, Hauger RL, Coste S, Stenzel-Poore M, Wurst W, Holsboer F (2009) CRF1 and CRF2 receptors are required for potentiated startle to contextual but not discrete cues. Neuropsychopharmacology 34:1494-1503. CrossRef Medline

Rodaros D, Caruana DA, Amir S, Stewart J (2007) Corticotropin-releasing factor projections from limbic forebrain and paraventricular nucleus of the hypothalamus to the region of the ventral tegmental area. Neuroscience 150:8-13. CrossRef Medline

Shaham Y, Erb S, Leung S, Buczek Y, Stewart J (1998) CP-154,526, a selective, non-peptide antagonist of the corticotropin-releasing factorl receptor attenuates stress-induced relapse to drug seeking in cocaine- and heroin-trained rats. Psychopharmacology 137:184-190. CrossRef Medline

Shaham Y, Shalev U, Lu L, De Wit H, Stewart J (2003) The reinstatement model of drug relapse: history, methodology and major findings. Psychopharmacology 168:3-20. CrossRef Medline

Shalev U, Finnie PS, Quinn T, Tobin S, Wahi P (2006) A role for corticotropin-releasing factor, but not corticosterone in acute food deprivation induced reinstatement of heroin seeking in rats. Psychopharmacology 187:376-384. CrossRef Medline

Shalev U, Erb S, Shaham Y (2010) Role of CRF and other neuropeptides in stress-induced reinstatement of drug seeking. Brain Res 1314:15-28. CrossRef Medline

Sinha R (2001) How does stress increase risk of drug abuse and relapse? Psychopharmacology 158:343-359. CrossRef Medline

Sinha R, Talih M, Malison R, Cooney N, Anderson GM, Kreek MJ (2003)
Hypothalamic-pituitary-adrenal axis and sympatho-adreno-medullary responses during stress-induced and drug cue-induced cocaine craving states. Psychopharmacology 170:62-72. CrossRef Medline

Sinha R, Shaham Y, Heilig M (2011) Translational and reverse translational research on the role of stress in drug craving and relapse. Psychopharmacology 218:69-82. CrossRef Medline

Sparta DR, Sparrow AM, Lowery EG, Fee JR, Knapp DJ, Thiele TE (2008) Blockade of the corticotropin releasing factor type 1 receptor attenuates elevated ethanol drinking associated with drinking in the dark procedures. Alcohol Clin Exp Res 32:259-265. CrossRef Medline

Specio SE, Wee S, O’Dell LE, Boutrel B, Zorrilla EP, Koob GF (2008) CRF(1) receptor antagonists attenuate escalated cocaine self-administration in rats. Psychopharmacology 196:473-482. CrossRef Medline

Sutherland JE, Burian LC, Covault J, Conti LH (2010) The effect of restraint stress on prepulse inhibition and on corticotropin-releasing factor (CRF) and CRF receptor gene expression in Wistar-Kyoto and Brown Norway rats. Pharmacol Biochem Behav 97:227-238. CrossRef Medline

Sztainberg Y, Kuperman Y, Tsoory M, Lebow M, Chen A (2010) The anxiolytic effect of environmental enrichment is mediated via amygdalar CRF receptor type 1. Mol Psychiatry 15:905-917. CrossRef Medline

Sztainberg Y, Kuperman Y, Justice N, Chen A (2011) An anxiolytic role for CRF receptor type 1 in the globus pallidus. J Neurosci 31:17416-17424. CrossRef Medline

Van Pett K, Viau V, Bittencourt JC, Chan RK, Li HY, Arias C, Prins GS, Perrin M, Vale W, Sawchenko PE (2000) Distribution of mRNAs encoding CRF receptors in brain and pituitary of rat and mouse. J Comp Neurol 428:191-212. CrossRef Medline

Wang B, Shaham Y, Zitzman D, Azari S, Wise RA, You ZB (2005) Cocaine experience establishes control of midbrain glutamate and dopamine by corticotropin-releasing factor: a role in stress-induced relapse to drug seeking. J Neurosci 25:5389-5396. CrossRef Medline

Wang B, You ZB, Rice KC, Wise RA (2007) Stress-induced relapse to cocaine seeking: roles for the $\mathrm{CRF}(2)$ receptor and CRF-binding protein in the ventral tegmental area of the rat. Psychopharmacology 193:283-294. CrossRef Medline

Zorrilla EP, Wee S, Zhao Y, Specio S, Boutrel B, Koob GF, Weiss F (2012) Extended access cocaine self-administration differentially activates dorsal raphe and amygdala corticotropin-releasing factor systems in rats. Addict Biol 17:300-308. CrossRef Medline

Zorrilla EP, Heilig M, de Wit H, Shaham Y (2013) Behavioral, biological, and chemical perspectives on targeting CRF1 receptor antagonists to treat alcoholism. Drug Alcohol Depend 128:175-186. CrossRef Medline

Zorrilla EP, Logrip ML, Koob GF (2014) Corticotropin releasing factor: a key role in the neurobiology of addiction. Front Neuroendocrinol 35: 234-244. CrossRef Medline 